\title{
LESSON STUDY: IMPROVING TEACHING SKILL FOR SENIOR HIGH SCHOOL TEACHER IN GUNUNGKIDUL
}

\author{
Oleh: Fariz Setayawan, Abdul Taram \\ Universitas Ahmad Dahlan \\ E-mail: fariz.setyawan@pmat.uad.ac.id
}

\begin{abstract}
Teaching skill is one of the important parts of mathematics education. It requires the teacher to make an innovation in the learning process. This study is a descriptive qualitative research. Therefore, the aim of this paper is to describe how far senior high school teacher implements lesson study in teaching and learning process. The result of the study found by observers that majority of the teachers has not implement lesson study. Most of the teacher thinks that it is difficult to implement lesson study due to a time management and a curriculum distinction. It was found that SMK 1 Patuk implement lesson study for the first time. The teacher thinks that lesson study helps both of the teacher and students in making a better learning. Teacher makes an innovation in the learning process. There are three benefits of using lesson study strategies. First, it helped the teacher to improve their teaching skills in the classroom. Second, it built Professional Learning Communities with a focus on Lesson Study. Third, it gave more information about student learning process in the classroom.
\end{abstract}

Keyword: Teaching Skill, Lesson Study, Learning Process

\begin{abstract}
Abstrak
Keterampilan mengajar adalah salah satu bagian penting dari pendidikan matematika. Hal ini membutuhkan guru untuk melakukan inovasi dalam proses pembelajaran. Penelitian ini merupakan penelitian deskriptif kualitatif. Oleh karena itu, tujuan dari makalah ini adalah untuk mendeskripsikan sejauh mana guru SMA menerapkan pelajaran pelajaran dalam proses belajar mengajar. Hasil penelitian yang ditemukan oleh pengamat bahwa mayoritas guru belum melaksanakan lesson study. Sebagian besar guru berpikir bahwa sulit untuk menerapkan lesson study karena manajemen waktu dan perbedaan kurikulum. Ditemukan bahwa SMK 1 Patuk melaksanakan lesson study untuk pertama kalinya. Guru berpikir bahwa pelajaran membantu kedua guru dan siswa dalam melakukan pembelajaran yang lebih baik. Guru membuat inovasi dalam proses pembelajaran. Ada tiga manfaat menggunakan strategi lesson study. Pertama, ini membantu guru untuk meningkatkan kemampuan mengajar mereka di kelas. Kedua, membangun Komunitas Pembelajaran Profesional dengan fokus pada Lesson Study. Ketiga, ia memberi lebih banyak informasi tentang proses belajar siswa di kelas.
\end{abstract}

Kata kunci: Keterampilan Mengajar, Lesson Study, Proses Belajar

\section{A. INTRODUCTION}

There are four competencies that all of the teachers must have in the learning process. One of them is professional and pedagogics competences. Professional competence is a competence of the teacher whom is mastering the learning material which is transferred to the students. Pedagogics competences is a competence of the teacher whom delivered the learning materials to the students. Besides four competences, pedagogics competences are important for teacher during teaching and learning process. One of pedagogics competence is teaching skill. Teaching skill can be improved if the teacher using open class to evaluate their competence in managing the class. One strategies which is facilitate teacher to evaluate the teacher in open-class condition is lesson study. 
Lesson study is a collaborative and collegial strategies which evolves from Professional Learning Communities (PLCs) of teachers, provides opportunities to create a model for high-quality instructional practices, and improves a lesson through teacher collaboration. It allows teacher to consider the objectives of a particular content area, unit and/or lesson, plan lessons that bring to life both short-term and long-term goals, deepen subject matter knowledge, develop pedagogy, share and design best practices, participate in job-embedded learning, explore problems that impede student learning, and understand how students think and learn. There are at least two benefits of using lesson study in class. First, skill development in other professional learning activities related to Lesson Study Support of fellow teachers in initiating, Second, building Professional Learning Communities with a focus on Lesson Study.

As the researcher's experience in implementing lesson study, it is difficult to evaluate the teaching skill of the teacher in class. By lesson study, the observers spend their attention to a specific group of students in learning. Consequently, the observation in learning activities can be seen individually. There is two observation that can be implemented in the classroom. First, direct observation can be seen by the interaction between students, teacher, and learning materials in the classroom. Second, indirect observation is seen by students' paper work. By observation in the classroom, lecturers find an information or learning materials which are appropriate to students' need.

In this study, researcher implement lesson study in Gunungkidul Senior High Schools. The paper explores the benefits of using lesson study, challenges associated with students' participation in class, and assessment of students' activities in class.

\section{B. RESEARCH METHOD}

The study is taking place in SMA/SMK Gunungkidul. This is a descriptive qualitative research. It describes the benefits of using Gallery walk strategies which are used in learning while doing lesson study. There are 6 observers whom they are involved in three cycles of lesson study. The explanation about each cycle in the learning process is described as follows.

\section{Plan}

Teacher prepares the materials related to the material of learning. Teacher divides students in the group that consists of 4-5 students. There are 7 groups who discuss the same problems. Students' participation is observed by using Abuid's (2014) Questionnaire. Observers fill the questionnaire using yes or no answers.

\section{Do}

By using lesson study, lecturer gives problems related to the material of learning. Students solve the problem in the group. One of the groups presents their discussion in front of the class. Each student must contribute in discussion in group.

\section{See}

After teaching and learning process, lecturers evaluate the strategies of learning that have been used. Teachers plan the appropriate strategies in the next session. Teachers reflect students' participation and paper works. 
Diterbitkan oleh Lembaga Pengabdian kepada Masyarakat

Universitas Ahmad Dahlan Yogyakarta

Each stage has been reflected both the teaching and learning process and the learning materials. Based on reflection paper, lecturer plan the next learning material with the observers. Each material is discussed for the mathematics education students.

\section{RESULT AND DISCUSSION}

Several positive outcomes were observed. The teacher reported that they had greatly enjoyed the activity and wished to repeat in the future. Students were particularly excited at the chance to view their own work. Students also reported great satisfaction with several other capabilities of the problem-solving activities. The feedback from observers related to the participation of the students in the classroom is shown in Table 1.

Based on table 1 it is shown that most of the observer gives a positive response related to the teacher's performance. Most teacher thought that the teacher make a good improvement in using medium of learning to deliver materials. Besides, there are challenges associated with students' participation in problem-solving activities, such as time of learning. On the other hand, the observers found that time synchronization between the observers will be a treat to apply lesson study in the class. It is because observers have their own schedule to teach mathematics in class. The difficulties will be solved if the learning is planned well with commitment. It was found that lesson study is one of the best alternatives to improve teaching skill of teacher in SMA/SMK Gunungkidul.

\section{CONCLUSION}

There are three benefits of using lesson study strategies. First, it helped teacher to improve their teaching skill in the classroom. Second, it is building Professional Learning Communities with a focus on Lesson Study. Third, gallery walk gives more information about student learning process in the classroom.

\section{REFERENCE}

Abuid, B. A. (2014). A student participation assessment scheme for effective teaching and learning. Learning and Teaching in Higher Education, 11(1), 1-27. Retrieved from http://lthe.zu.ac.ae 
